Comment

\title{
Anthropocene Shiftings: Response to Perego, E. and Scopacasa, R. The Agency of the Displaced? Roman Expansion, Environmental Forces, and the Occupation of Marginal Landscapes in Ancient Italy. Humanities 2018, 7, 116
}

\author{
Carol Farbotko (D) \\ School of Geography, The University of Melbourne, Carlton 3053, Australia; carol.farbotko@csiro.com.au
}

Received: 16 September 2019; Accepted: 25 September 2019; Published: 10 October 2019

check for updates

\begin{abstract}
In this response to Elisa Perego and Rafael Scopacasa's article, I reflect on connections across time and space from an Anthropocenic perspective that is, by urgent necessity, open to the unexpected. In Ancient Italy, and contemporary Tuvalu and Brazil, it is possible to find similarly unexpected ends being achieved among populations that move, whose lives are lived on ground that cannot be assumed to be inert: earth has agency, and over time, it shifts, or is flooded, or buries things. When non-elites are moving into marginal places where life is tough, where earthly agency cannot be ignored, such people are also finding themselves at the centre of major turning points in history. Mobility and survival in marginal places can offer a way to live a less colonized life.
\end{abstract}

Keywords: Anthropocene; decolonized mobility; agency

Who belongs to the Banaban soil that was dispersed across the New Zealand landscape?

Katerina Martina Teaiwa (2005), “Our Sea of Phosphate”

Some stories say our ancestors came from volcano stone

Lidrepdrepju—a basalt rock goddess rooted in reef

Today I keep a basalt rock on my bookshelf

What tokens of our land shall we/will we

store in our selves

inside our honeycomb of chest bones

the buzzing of a shore long gone

Kathy Jetñil-Kijiner (2017) extract from "Butterfly Thief"

Perego and Scopacasa (2018, p. 2) ask a question that is equally applicable in Ancient Italy as it is in contemporary Brazil and the Pacific Islands: "how, and in what circumstances, can human agency rework the negative effects of social and environmental constraints, and channel them towards unexpected ends?" Their piece, Agency of the Displaced? Roman Expansion, Environmental Forces, and the Occupation of Marginal Landscapes in Ancient Italy, offers an opportunity to look for connections across time and space, from an Anthropocenic method of inquiry that is, by urgent necessity, open to the unexpected. Issues of agency, place and mobility considered in a study of the rural lives of non-ruling populations of the Roman Empire, are in turn shaped by reflecting on agency in informal settlements in contemporary Brazil. And from Ancient Italy, the Anthropocene comfortably allows a turn towards the atoll islands of the Pacific, since all is now understood to be intricately interconnected: 
There is nowhere to stand "outside" of things, no objectively bound space from which to stand aside and document ... everything becomes humbled within the Anthropocene's vast, intensified realm of relationships. (Chandler and Pugh 2018, p. 4)

In the Anthropocene, space, time, and power are layering in complex ways as the Earth reveals itself to be both utterly vulnerable to human activity while also having agency that humans cannot entirely control (Hamilton 2017). With the Anthropocene upon us, archaeologists and historians have much to offer other disciplines, such as mine, human geography, that, except for historical geography, are often only casually tuned into the importance of the temporal. The notion of the dig, for instance, offers geography-rich ideas of material circulation and sedimentation, constitutive of constantly enfolding, unfolding histories and cultures. Geography' spaces and places, dynamic as they are, need to be more alive to the layers of time. So, if the Daunians "found themselves at the centre of major turning-points in history", might their rural shift be understood as a response to a sensed forthcoming existential upheaval (Perego and Scopacasa 2018, p. 2)? The age of the Anthropocene renders such questions relevant across time and space. While geographers have highlighted that the Anthropocene is not only a geological era but also a spatial system, "a human-dominated biosphere challenging the resilience of a livable planet" (Carpenter et al. 2019, np), history reminds geography to beware of snapshots. We are facing a new future in which humans may not exist, at our own hands, so we must rethink both what we know, and how we know it (Brondizio et al. 2016; Lövbrand et al. 2015). In Ancient Italy, and contemporary Tuvalu and Brazil, it is possible to find similarly unexpected ends being achieved among populations that move, whose lives are lived on ground that also cannot be assumed to be inert: it has agency, and over time, it shifts, or is flooded, or buries things. The unexpected is the self-sufficiency of everyday people, moving into marginal places where life is tough, where earthly agency cannot be ignored. Since rationalist, technocentric, often paternalistic approaches to problem-solving are failing at the global scale, it seems urgent and necessary to "become better attuned to material interruptions of common sense" - the unexpected - which may have "the potential to help those in privileged positions feel the urgency of what they cannot yet see" (Erev 2019, p. 16). Perego and Scopacasa (2018) present a case for unexpected resilience following mobility into areas possibly affected by unstable climate conditions, away from centres of power. In the current era of unsolved climate change, perhaps it is the elites who must learn from those who already are tuned into the coming catastrophe, and mobilizing in various ways, including to sites of survival.

There is an (externally created) common sense of what is happening in low-lying islands in the Anthropocene: These are islands that are entirely low-lying in the face of a warmed, encroaching ocean. They have no higher ground for retreat. People's homes will become increasingly waterlogged, lands will erode away, and crops and water supplies will become increasingly salty as the water moves in. In this type of account, very common in climate change narratives (Farbotko 2012), it is important that only water is accorded agency. People and their land are accorded surprisingly little. This matters because privileging the agency of water enables complex land-people relations to be conveniently reduced to one question in geopolitical debate: what will happen to 'climate refugees'? Without recognised agency of people or land, there seems little option for affected populations but to leave, destitute, arriving someplace else, as a "problem" for the international community to solve. This is a colonization of conceptual space that adds to the multiple colonizations of the Pacific Islands. Yet, there are other conceptualizations, where the agency of people and non-watery territory is acknowledged, particularly among the affected populations themselves (Suliman et al. 2019; Farbotko 2012). Central to many Pacific Island indigeneities is the ancient concept of *banua, meaning an inhabited territory which included the village and its population along with everything that contributes to the life support system of that community (Blust 1987). *Banua became, and remains, highly specific to particular places, for example, vanua in Fiji, fonua in Tonga, and whanua in New Zealand. But this particularity became possible because of *banua's mobility and adaptiveness, and its endurance over time. The ancient Austronesian people were highly mobile, travelling over a period of several thousand 
years, through southeast Asia and, into the remote islands of the Pacific Ocean, taking *banua with them (Suliman et al. 2019).

Interruptions to the 'common-sense' account of sea-level rise take multiple forms among the activists, artists, scholars, spiritual leaders and others in the Pacific Islands, who argue convincingly for their own knowledges to be forefront in the advancement of sustainable Pacific futures (e.g., Duittuturaga 2017; Lagi 2017; Lumā Vaai 2017; Māhina 2008; Nabobo-Baba 2006; Thaman 2002; Trask 1991). Thus far, the potential in Pacific knowledge to enable Pacific people to survive the Anthropocene on their own terms has likely been far from fully realised (Duittuturaga 2017; Lumā Vaai and Casimira 2017; Long 2017; Māhina 2008). Just one example: unbound from the constraints of colonizing knowledge, Pacific poets and writers intimately know the connections between indigeneity and colonizing agriculture, distant in time and space but nevertheless connected through the colonized substance called phosphate, belonging to Banabans and Nauruans of the Pacific. Banabans and their phosphate-rich land were displaced and dug up from Banaba to ensure that farms were productive in Australia and New Zealand. Today, Pacific workers pick fruit in Australia alongside backpackers and undocumented migrants, doing work which residents of Australia find too difficult and too low paid (Howe et al. 2019). Australian horticulture would not thrive without Pacific people: their phosphate, their bodies, their mobilities, connections which colonial powers still cannot or will not see (Teaiwa 2005; Kihara 2019). Teaiwa (2005, p. 187) writes of the 'political and poetic resonances between the past and the present, and the very material or organic forms in which such resonances were embedded.' Teaiwa (2005) showed how, with phosphate, indigeneity moves and does not disappear across geopolitical boundaries, albeit with injurious impacts on rights to self-determination. Banaba itself is moving through colonial systems. This unboundedness of place enables the survival of indigeneity. Place moves in order for indigenous people to remain resilient in a world where the powerful find multiple ways to uproot people and exploit their land.

My own work in Tuvalu focuses on agency of the potentially displaced (e.g., Farbotko 2012). On my most recent study visit (an as-yet-unpublished data set) (Farbotko 2019), I observed a coherent movement of urban dwellers into a marginal, rural, coastal site-Funafala—accessible only by boat. Funafala is valued by those moving there as a place that enables indigeneity away from the busy capital. Urban-rural migration is not 'expected,' but is happening nonetheless. The residents of Funafala are well aware of both climate risks and climate geopolitics, but are choosing to move to a culturally important site in defiance of expectations of sea-level rise and lack of services or employment. Further, this is not the only movement observable in Tuvalu, and not all movement is of humans. Some is only detectable to local experts, some to scientists. Sand is being dredged from the lagoon in an attempt to protect and build up land. Dredging changes lagoon dynamics, creating new patterns of sand and water. Tuning into these dynamics, coastal geomorphologists and local knowledge holders on atolls have long known that atolls are dynamic configurations of land and sea, so any attempt to measure sea-level rise must take this dynamic into account (Webb and Kench 2010; Yarina and Takemoto 2017). Social life on atolls is embedded in this dynamism.

Land expansion, requiring continued maintenance, was conducted before colonial forces intervened. On Rongelap atoll in the Marshall Islands, human-produced land expansion halted when people were relocated following the use of their island for nuclear experimentation, and land reverted to its unexpanded form. This reversion of the land mass would appear "to the untrained eye or the unprepared scientist [ ... ] to be erosion of an island and possibly the effects of global climate change" (Bridges and McClatchey 2009, p. 145). Traditional land boundaries, furthermore, are also redefined on atolls as land shifts, as productive land is rested, and as harvesting is moved to other areas (Yarina and Takemoto 2017; Bridges and McClatchey 2009). Social agency and land agency intermingle. None of this disproves climate change impacts, but rather serves as a reminder that, in the Anthropocene, multiple perspectives are necessary, and what we think we know is only ever a partial account of a larger, dynamic system that is unfolding over time as well as at multiple scales, from the micro to the global: 
An island is continuously being made and unmade, through human and non-human activities and processes that interact with the performances of sand. Therefore, there is no specific start or end point to the life of an island; what an island is-how it constitutes the lifeworlds of those living on it-is never complete but is continually under construction. (Kothari and Arnall 2019, p. 9)

But when this process of 'construction' involves acts of artificial land reclamation, this can also impact the agency of those living on the original land. Kathy Jetñil-Kijiner, an artist whose homeland is the low-lying Marshall Islands, is calling for new balms for the 'raw grief' being experienced about land reclamation as a response to sea-level rise. The artificiality of new land does not satisfactorily address the emotions wrought by climate change, as shared in her reflection entitled 'rituals for artificial islands':

Building islands or even just elevating would mean ripping apart our land, and with it the roots of our culture, as well as displacing/uprooting thousands of people in the process, and using processes that could destroy precious reefs. It's extreme, and desperate. (Jetñil-Kijiner 2019, np)

It seems that reclaimed land, if it is to calm and not cause raw grief associated with climate change impacts, will need to be decolonized:

No island was ever an island to begin with. Thus, no island is an island. Never was, never will be. At least this is how I cling on to islands in the advanced wake of their disappearance on account of rising waters. (Diaz 2011, p. 28)

Diaz's argument is that islands are colonial, continental constructs, as Dan-el Padilla Peralta (2019, p. 3) puts it, 'doomed never to be a piece of the continent, a part of the main.' For Jetñil-Kijiner, a 'basalt rock on a bookshelf' stands ready to remind of the loss of atoll place today and tomorrow, if artificial islands are not attentive to the culture and ancestry of people for which they are constructed. Land reclamation is occurring in the urban area that Funafala people are leaving. Island people are keeping close track of their indigeneity, wherever they go, and protecting it in unexpected ways.

Returning to the question of the shift to the rural in the time of possibly unstable climatic conditions in the Roman empire examined by Perego and Scopacasa, the unexpected has significant contemporary lessons. Among communities who find themselves at the centre of major turning points in history, an ability to survive in a marginal place is not only possible, but desirable, if it offers a way to live a less-colonized life. As in ancient Canusium, trade-offs in sustenance and other resources might be acceptable for freedoms gained from elites, colonizers, artificial—or marginalized, in the case of Daunia-land that does not feel like home, and other powerful forces. As the rest of humanity contemplates our ability to cause, but perhaps not prevent, our own demise, it might be useful to attempt to learn more about decolonized survival from those who were, as in ancient Canusium, or are, in the case of atoll populations, still tuned deeply into the earth's agency (Erev 2019).

Funding: This research was funded by Committee for Research and Exploration of the National Geographic Society, grant number HJ2-194R-18.

Conflicts of Interest: The author declares no conflict of interest. The funders had no role in the design of the study; in the collection, analyses, or interpretation of data; in the writing of the manuscript, or in the decision to publish the results. 


\section{References}

Blust, Robert A. 1987. Lexical Reconstruction and Semantic Reconstruction: The Case of Austronesian 'House' Words. Diachronica 4: 79-106. [CrossRef]

Bridges, Kent W., and Will C. McClatchey. 2009. Living on the margin: ethnoecological insights from Marshall Islanders at Rongelap atoll. Global Environmental Change 19: 140-46. [CrossRef]

Brondizio, Eduardo S., Karen O’Brien, Xuemei Bai, Frank Biermann, Will Steffence, Frans Berkhout, Christophe Cudennec, Maria Carmen Lemosh, Alexander Wolfe, Jose Palma-Oliveira, and et al. 2016. Re-conceptualizing the Anthropocene: A call for collaboration. Global Environmental Change 39: 318-27. [CrossRef]

Carpenter, Stephen R., Carl Folke, Martin Scheffer, and Frances R. Westley. 2019. Dancing on the volcano: Social exploration in times of discontent. Ecology and Society 24: 23. [CrossRef]

Chandler, David, and Jonathan Pugh. 2018. Islands of relationality and resilience: The shifting stakes of the Anthropocene. Area. [CrossRef]

Diaz, Vincente M. 2011. Voyaging for anti-colonial recovery: Austronesian seafaring, archipelagic rethinking, and the re-mapping of indigeneity. Pacific Asia Inquiry 2: 21-32.

Duittuturaga, Emele. 2017. Rethinking development, reshaping the Pacific we want. In Relational Hermeneutics: Decolonising the Mindset and the Pacific Itulagi. Edited by Upolu Lumā Vaai and Aisake Casimira. Suva: University of the South Pacific Press and Pacific Theological College, pp. 199-214.

Erev, Stephanie. 2019. Feeling the Vibrations: On the Micropolitics of Climate Change. Political Theory. [CrossRef]

Farbotko, Carol. 2012. Skilful seafarers, oceanic drifters or climate refugees? Pacific people, news value and the climate refugee crisis. In Migrations and the Media. Edited by Kerry Moore, Bernhard Gross and Terry Threadgold. New York: Peter Lang Publishing, pp. 119-42.

Farbotko, Carol. 2019. Climate displacement and the right to return. Paper presented at the A Mobilities Lens to the Human Mobility-Environmental Change Nexus Symposium, Wageningen, The Netherlands, June 6-7.

Hamilton, Clive. 2017. Defiant Earth: The Fate of Humans in the Anthropocene. Cambridge and Malden: Polity Press.

Howe, Joanna, Stephen Clibborn, Alexander Reilly, Diane van den Broek, and Chris F Wright. 2019. Towards a Durable Future: Tackling Labour Challenges in the Australian Horticulture Industry. Adelaide: University of Adelaide.

Jetñil-Kijiner, Kathy. 2017. Butterfly Thief and Complex Narratives of Disappearing Islands. Available online: https: //www.kathyjetnilkijiner.com/butterfly-thief-and-complex-narratives-of-disappearing-islands/ (accessed on 9 September 2019).

Jetñil-Kijiner, Kathy. 2019. Bulldozed Reefs and Blasted Sands: Rituals for Artificial Islands. Available online: https://www.kathyjetnilkijiner.com/bulldozed-reefs-and-blasted-sands-rituals-for-artificial-islands/ (accessed on 9 September 2019).

Kihara, Yuki. 2019. Pick our Fruit. Available online: https://www.samoaobserver.ws/category/samoa/47622 (accessed on 9 September 2019).

Kothari, Uma, and Alex Arnall. 2019. Shifting sands: The rhythms and temporalities of island sandscapes. Geoforum. in press. [CrossRef]

Lagi, Rosiana. 2017. Vanua Sauvi: Social roles, sustainability and resilience. In Relational Hermeneutics: Decolonising the Mindset and the Pacific Itulagi. Edited by Upolu Lumā Vaai and Aisake Casimira. Suva: University of the South Pacific Press and Pacific Theological College, pp. 187-97.

Long, Maebh. 2017. Vanua in the Anthropocene: Relationality and Sea Level Rise in Fiji. Symplokē 26: 51-70. [CrossRef]

Lövbrand, Eva, Silke Beck, Jason Chilvers, Tim Forsyth, Johan Hedrén, Mike Hulme, Rolf Lidskog, and Eleftheria Vasileiadou. 2015. Who speaks for the future of Earth? How critical social science can extend the conversation on the Anthropocene. Global Environmental Change 32: 211-18. [CrossRef]

Lumā Vaai, Upolu. 2017. E itiiti a lega mea-Less yet More! A Pacific Relational Development Paradigm of Life. In Relational Hermeneutics: Decolonising the Mindset and the Pacific Itulagi. Edited by Upolu Lumā Vaai and Aisake Casimira. Suva: University of the South Pacific Press and Pacific Theological College, pp. 215-31.

Lumā Vaai, Upolu, and Aisake Casimira. 2017. Introduction: A relational renaissance. In Relational Hermeneutics: Decolonising the Mindset and the Pacific Itulagi. Edited by Upolu Lumā Vaai and Aisake Casimira. Suva: University of the South Pacific Press and Pacific Theological College, pp. 1-14. 
Māhina, Hūfanga 'Okusitino. 2008. From vale (ignorance) to 'ilo (knowledge) to poto (skill) the Tongan theory of ako (education): Theorising old problems anew. AlterNative: An International Journal of Indigenous Peoples 4: 67-96. [CrossRef]

Nabobo-Baba, Unaisi. 2006. Knowing and Learning. An Indigenous Fijian Approach. Suva: Institute of Pacific Studies, University of the South Pacific.

Padilla Peralta, Dan-el. 2019. Citizenship's Insular Cases, from Ancient Greece and Rome to Puerto Rico. In Displacement and the Humanities: Manifestos from the Ancient to the Present. Edited by Elena Isayev and Evan Jewell. Special issue, Humanities 8: 134. Available online: https://www.mdpi.com/2076-0787/8/3/134 (accessed on 5 September 2019).

Perego, Elisa, and Rafael Scopacasa. 2018. The Agency of the Displaced? Roman Expansion, Environmental Forces, and the Occupation of Marginal Landscapes in Ancient Italy. In Displacement and the Humanities: Manifestos from the Ancient to the Present. Edited by Elena Isayev and Evan Jewell. Special issue, Humanities 7: 116. Available online: https://www.mdpi.com/2076-0787/7/4/116 (accessed on 5 September 2019).

Suliman, Samid, Carol Farbotko, Hedda Ransan-Cooper, Karen Elizabeth McNamara, Fanny Thornton, Celia McMichael, and Taukiei Kitara. 2019. Indigenous (im)mobilities in the Anthropocene. Mobilities 14: 298-318. [CrossRef]

Teaiwa, Katerina M. 2005. Our Sea of Phosphate: The Diaspora of Ocean Island. In Indigenous Diasporas and Dislocation. Edited by Graham Harvey and Charles D. Thompson. Burlington: Ashgate Publishing, pp. 169-91.

Thaman, Konai H. 2002. Shifting sights: the cultural challenge of sustainability. Higher Education Policy 15: 133-42. [CrossRef]

Trask, Haunani-Kay. 1991. Natives and anthropologists: The colonial struggle. The Contemporary Pacific 3: 159-67. Webb, Arthur P., and Paul S. Kench. 2010. The dynamic response of reef islands to sea-level rise: evidence from multi-decadal analysis of island change in the Central Pacific. Global and Planetary Change 72: 234-46. [CrossRef]

Yarina, Elizabeth, and Shoko Takemoto. 2017. Interrupted Atolls: Riskscapes and Edge Imaginaries in Tuvalu. The Plan Journal 2: 461-95. [CrossRef]

(C) 2019 by the author. Licensee MDPI, Basel, Switzerland. This article is an open access article distributed under the terms and conditions of the Creative Commons Attribution (CC BY) license (http://creativecommons.org/licenses/by/4.0/). 